\title{
TRAGEDIAN POLITIIKASTA
}

I TRAGEDIA JA MURHENÄYTELMÄ CARL SCHMITTILLÄ JA WALTER BENJAMINILLA

NÄYTELMÄSTÄ TRAGEDIAAN

Kiihko jolla aikamme haluaa paljastaa politiikkojen julkisten naamioiden takaa yksityisen henkilön ja tämän itsekkäät intressit kertoo siitä, miten vahvasti moderni porvarillinen käsitys politiikasta yksityisten intressien fasadina on syrjäyttänyt teatraalisen näkemyksen politiikasta julkisena roolina. ${ }^{1}$ Kun politiikkaa syytetään tänään teatraalisuudesta tarkoitetaan kuitenkin usein, että kykenemättömänä vakaviin päätöksiin siitä on tullut demokraattiselle yleisölle suunnattua kansan viihdettä. Perustavan päätöksen ongelman unohtaminen oli traagisen perustan ajattelijan, Carl Schmittin, kritiikki modernia politiikkaa kohtaan. Schmittille teatteri näytelmänä on peliä ja leikkiä ja siten olemuksellisesti vakavan poikkeustilanteen kieltämistä. Juristina Schmitt määritteli näytelmän laillistetuksi vapaa-ajaksi, joka on mahdollista vasta kun traaginen, esioikeudellinen konfliktin tila on ratkaistu. "Tragedia loppuu siellä missä näytelmä alkaa, silloinkin kun näytelmä on melankolinen." Traagista toimintaa on mahdotonta keksiä tai suhteellistaa eli näytellä. Keksitty kohtalo ei ole mikään kohtalo, ja siksi yksikään moderni nero ei voi luoda tragedian ydintä, joka ei piile subjektiivisen neron luovassa mielikuvituksessa vaan yhteisessä ja jaetussa julkisen alueen perustavassa historiallisessa totuudessa. ${ }^{3}$

Walter Benjaminia seura- ten Schmitt muistuttaa, että barokkiajan ilmapiirissä toiminnan miehet näkivät itsensä vielä näyttämöllä ja että toiminta julkisella alueella oli roolipeliä. ${ }^{4}$ Myös Michel Foucault muistutti aina barokkipolitiikan spektakulaarisesta luonteesta ja yhdisti uuden ajan tragediat absoluuttisen valtion suverenisuuden juridis-teologiseen oikeuttamiseen. Varsinkin hovin ympärille keskittyvät Racinen tragediat olivat osa hallitsijan ritualisoitua spektaakkelia. ${ }^{5}$ Schmittille taas Racinen ja Corneillen klassiset näytelmät eivät ole todellisia tragedioita, sillä niiden suljettu muoto, oikeudellinen ajan, paikan ja toiminnan ykseys pystyi ilmaantumaan ainoastaan julkisen rauhan ja järjestyksen tiukassa kehikossa, mannermaisessa suvereenissa valtiossa, joka oli ratkaissut tunnustuksellisten uskonsotien verisen ja traagisen omatuntojen konfliktin. ${ }^{6}$ Sen sijaan mannermaisen valtion juridisen kehikon kiertävässä, keskiajasta lähes suoraan merivallaksi kehittyneessä ja sitten teollistumisen aloittaneessa Elisabetin Englannissa teatraalisuus oli perusteettomampaa, elävämpää ja alkukantaisempaa. Se oli "barbaarisempaa" vastakohtana mannermaisen valtion järjestykselle, ja siksi Voltaire voi nähdä Shakespearessa juopon villin ja Saksan Sturm und Drang käytti tätä taistossaan ranskalaista draamaa vastaan. Vitaalisemman, alkeellisemman ja avoimemman luonteensa tähden se voitiin yhdistää intensiivisemmin ajankohtaiseen todellisuuteen. Se salli historian tunkeutumisen näytelmään. Schmittille Hamletin traagisuus piileekin hahmon yhteydessä Jaakko I:een. Hamletissa Shakespeare kohotti aktu- aalisen historiallisen tilanteen eläväksi myytiksi ja muunsi murhenäytelmän tragediaksi. Kahdentamalla näyttämön kolmannessa kohtauksessa Shakespeare ei pyrkinyt erottamaan näytelmää todellisesta tilanteesta, kertomaan metadiskurssilla, että se mitä näette on vain näytelmää. ${ }^{7}$ Tarkoitus ei ollut myöskään erottaa teatterin jumalia Forumin jumalista, vaan esittämällä puhtaan näytelmän, esteettisen näytelmän näytelmässä Shakespeare toi epäsuorasti historiallisen tilanteen konkreettisen todellisuuden Hamletiin. Kun Priamin kuolemasta kertova näyttelijä vuodattaa kyyneliään, ei Hamlet ymmärrä tätä tyhjää esteettistä itkua: "Mit oli Hekuba hälle tai hän Hekuballe, Ett' itkis häntä? Mitäpä, jos hällä, Ne syyt ja vihjat vimmaan ois kuin mulla."

Näyttelijän itku auttaa Hamletia erottamaan puhtaan esteettisen kaihon ja konkreettista päätöstä vaativan tilanteen. Hamlet vapautuu päättämättömyydestään toteuttaakseen koston. Kyse ei ole enää puhtaan näytelmän esteettisestä tahdosta tahtomassa itseään, vaan näytelmästä tulee tragedia, jonka ydin on juuri erityiseen historialliseen tilanteeseen liittyvä toiminta. Schmittille Hamletissa Shakespeare irrotti konkreettisesta poliittisesta tilanteesta muodon, jonka kohotti myytin tasolle. Myyttiin perustuva antiikin tragedia taas välitti tämän kautta ei vain satunnaisen kirjallisen aiheen vaan yhteisesti jaetun ja eletyn todellisuuden.

TRAGEDIASTA NÄYTELMÄ̈̈N

Keskeinen lähde Schmittin pohdinnoille tragedian ja murhenäytelmän eroista oli Wal- 
ter Benjaminin Ursprung des deutschen Trauerspiels, joka itsessään oli saanut vaikutteita Schmittin suvereniteettia koskevista ajatuksista.? Juuri Schmitt, suvereniteetin teoreetikko, ja Benjamin, suvereniteetin vastakäsitteen, messiaksen teoreetikko, näyttävät edelleen olevan kaksi poolia, joiden välillä keskustelu perustan ongelmasta pyörii. ${ }^{10}$ Kuitenkin Benjaminille, joka myös korosti murhenäytelmän ja tragedian historiallista luentaa, Hamletia ei tule lukea tragediana.

Sen sijaan Hamletissa hämärä, julma ja vieraantunut, vaille lunastusta ja armoa, fysikaalisten voimien armoille heitetty saksalaisen murhenäytelmän katastrofaalinen melankolinen hahmo vihdoinkin lunastetaan. Melankolia on Benjaminille suurempien henkien vastaus sekularisaation lumouksen haihtumiseen, niiden, joille pelastuksen korvikkeeksi ei kelpaa vain työetiikka. Melankolia on itse elämän asettama protesti pragmatistiselle nihilismille. ${ }^{11}$ Hamlet, melankolinen ruhtinas, joka ei löydä pragmatistisesta valtaan pääsystä ainoaa elämänsä tarkoitusta, ei myöskään enää huku armottomaan historiaan, vaan tuo armottomuus kohdataan itsessään kirkkaassa itsetietoisuudessa. ${ }^{12}$ Näin Hamlet näyttäisi lupaavan profetian uudesta alusta. Hamletin satunnainen kuolema ei ole huonoa tragediaa.

"Hamletin kuolema, jolla ei ole sen enempää yhteyttä traagiseen kuolemaan kuin prinssillä itsellään on Ajaxiin, on räikeässä ulkoisuudessaan surunäytelmälle ominaista ja vain tämän tähden luojansa arvoinen: Hamlet, kuten on selvää tämän keskustelusta Osiriksen kanssa, haluaa hengittää kohtalon tukehduttavaa ilmaa yhdellä syvällä henkäyksellä. Hän haluaa kuolla jonkin sattuman johdosta."13

Tragedian päättyessä päätökseen on murhenäytelmän olemuksessa kaihonsa lunastusta etsivän marttyyrin viimeinen vetoomus transsendentille maailmassa, jossa kaikki suora yhteys tuonpuoleiseen kiellettiin. ${ }^{14}$ "Barokki ei tunne eskatologiaa." 15 Se voi etsiä vain puhtaasta luomisen tilasta lohdutusta armon häviämiseen. Yhteys historialliseen kohtaloon ja kronikkaan erottaa murhenäytelmän ajattomimpiin historiaa edeltäviin legendoihin perustuvasta kreikkalaisesta tragediasta, mutta barokilta puuttuu myös keskiajan kristillisen kronikan pelastushistoria, jossa maallisten tapahtumien turhuus on vain askelmia tiellä pelastukseen. Murhenäytelmää taas luonnehtii maallisen tilan täydellinen lohduttomuus, jonka vastakohdaksi ei asetu enää tuonpuoleinen ikuisuus vaan historian sekularisoiminen luomisen tilassa, paratiisin ajattomuuden palauttaminen. ${ }^{16}$ Barokin pastoraali-teemassa sekularisaatio johtaa kronologian spatialisaatioon, jossa historia on hajautettu kaikkialle maisemaan ja myös murhenäytelmässä "historia lomittuu näyttämöön". ${ }^{17}$ Vastoin tragedian päätöstä, joka rikkoo ajallisen jatkumon, murhenäytelmässä kronologinen liike esitetään hovin ajattomasssa tilassa lähes fysikaalisten voimien ja tendenssien luonnonhistoriana ${ }^{18}{ }^{\text {Historiasta ja }}$ luonnosta tulee lähes identtisiä ja ne löytävät ilmaisunsa suvereenista hallitsijasta, ihmiskunnan ja historian edustajassa, "joka pitää historian suuntaa käsissään valtikan tavoin." 19 Benjaminille tämän "entisöinnin" ja palauttamisen ideaalin antiteesinä barokissa kummittelee myös historiallisen katastrofin idea. Benjaminin mukaan Schmittin analysoima poikkeustilan perustuslaillinen oppi asetetaan vastauksena juuri jälkimmäiseen. ${ }^{20}$ Barokki yrittää sulkea ulkopuolen, poikkeustilan, ulos kahdesti. Tyrannin tulee palauttaa järjestys poikkeustilassa ja korvata historiallisen sattuman ennakoimattomuus luonnonhistoriaa muistuttavilla teräksisillä laeilla. Marttyyri-draaman siveä ruhtinas taas pyrkii asettamaan vastaavan linnoituksen ulkoisia sattumia vastaan sieluunsa käyttäen stoalaista tunteiden hallintaa. Tyranni ja marttyyri ovat absoluuttisen barokkihallitsijan kahdet kasvot. Murhenäytelmässä ei ole kyse pakanallisesta hallitsijan jumaluudesta ja hallitsijan teokraattisuuskin on enää vain jäänne. Hallitsijan absoluuttisuus ei tarjoa maallisesta vapauttavaa yhteyttä tuonpuoleiseen. Luomakunnan ja historian herra ei vapaudu oman luonnollisen ruumiinsa petomaisuudesta. "Hän on luotujen herra, mutta jää itse luoduksi." 21 Samaan aikaan kun päätöksestä tulee käskevä, siitä tulee lähes mahdoton. "Ruhtinas, joka on vastuussa poikkeustilan julistamisesta, paljastaa ensimmäisen tilaisuuden tullen olevansa lähes kykenemätön päätöksen tekemiseen."22 Barokkityrannin hulluus ei ole vallan hybriksessä vaan absoluuttisen vallan ja luonnollisen ruumiin jännitteessä. Hallitsijan päättävää tahtoa heikentävät tunteet ja aistimukset, ja toiminnan sijasta esille nousee tyrannin lähes fysikaalinen hulluus ja sen vastakohtana marttyyri-sankarin fysikaalinen kärsimys. Absoluuttinen hallitsi- 
ja, jonka pitäisi transgressoida transsendentti tekemällä siitä maailman sisäinen osa, immanentti, sortuukin tyhjän transsendentin kuiluun. Päätökselle ei ole ulkoista pistettä. Lunastuksen toiveesta jää jäljelle vain allegorian melankolia (ilman symbolin taivaan ja maan yhteen keräävää "pelastusta") sekä näyttämö ja sen keinotekoisuus itsessään, koko maailman näytelmällisyys, joka esiintyy puhtaimmin espanjalaisessa murhenäytelmässä ja jonka romantiikka sitten perii. Tuolla näyttämöllä kuitenkin ohjat ottaa käsiinsä moraaliton laskennallinen mestaruus, juonittelija-opportunistin "pragmatistinen" koreografia ja kyyninen reaalipolitiikka. Barokkipolitiikan kahdet kasvot esittävät kaikesta oikeudenmukaisuuden lumouksesta maallistuneen koneellistetun laskelmoivan vallan ja katastrofaalisiin toimiin turvautuvan menetetyn messianistisen toiveen.

Siinä missä Schmitt asettaa varhaisteoksessaan laskelmoivaa konetta vastaan katolisen symbolin, taideteoksen, joka esittää yhteen kooten maan ja taivaan jännitteen ja konfliktin, Benjamin etsii allegorian fragmentaarisuudesta lunastavaa voimaa. ${ }^{23}$ Samoin antiikin tragediassa Benjamin ei juhli myytin yhteenkerävää monimielisyyttä, vaan Benjaminille tragediassa myytin monimielisyys on jo laskussa. Benjaminille tragedia historiallisena muotona on sidottu profeetalliseen agonismiin ja hegeliläisesti menneiden ja tulevien jumalien taisteluun. Benjaminille tragediassa pakana tajuaa olevansa jumaliaan parempi, mutta tämän tajuaminen varastaa häneltä puheen ja lyö hänet sanattomaksi. Traaginen kokemus koskee sanan konfliktia, johon löydetään sovitus vain hiljaisuudessa. Vastakkaisena spektaakkelimaiselle murhenäytelmälle, joka sitoutuu esittämiseen enemmän kuin sanoihin,${ }^{24}$ tragediaa ei voi ajatella pantomiimina. ${ }^{25}$ Rozenweigia seuravalle Benjaminille traaginen ironia loi dialogin vain esittääksen hiljaisuutta. Siinä missä tragedian sankarit ovat lähes sieluttomia, murhenäytelmään vaikuttanut marttyyridraama syntyy Benjaminin mukaan Sokrateen kuolemasta tragedian parodiana. Huolimatta yhteyksistään traagisiin sankareihin Sokrates kuolee vapaaehtoisena marttyyrinä. Sokrateen ironia on tämän "laskelmoivassa" hiljaisuudessa, ja sokraattisissa keskusteluissa hiljainen, traaginen omatunnon taistelu on korvautunut loistavilla dialogeilla, jotka tavoiteltava idea asioiden homonyyminä kerää yhteen aivan kuten Benjaminille taiteen ideaa voi tavoitella vain sen moninaisuuden kautta.

\section{ANTIIKIN TRAGEDIA JA POLITIIKAN PERUSTAN ONGELMA}

\section{ANTIIKIN TRAGEDIA}

Riippumatta Benjaminin ja Schmittin historiallisen tulkinnan painotuksesta olivat heidän ajatuksensa tragediasta ja murhenäytelmästä aikalaisintressiin ja modernin ongelmiin sidottuja. ${ }^{26}$ Moderni maailmamme onkin haluttu nähdä traagiseksi silloin kun on korostettu modernia kohtalon poissaolon kohtaloa ${ }^{27}$ tai sitten schmittiläisesti painotettu voimien traagista konfliktia maailmassa vailla perustaa $^{28}$ (Post-)modernin ba- rokkimaisuutta taas on etsitty aikamme spektaakkelimaisuudesta, mutta myös silloin kun aikamme on haluttu nähdä allegorisessa valossa, fragmentoituneena maailmana, jossa modernin lupausten raunioiden esteettisen melankolian alla historia näyttäytyy lunastusta vaille jääneenä epäjatkuvana katastrofina ja käytännöllinen poliittinen valta lepää opportunististen reaalipoliitikkojen mestarillisissa laskelmissa. ${ }^{29}$

Mutta jos jätämme nyt pitkäksi käyneen johdannon ja Schmittin ja Benjaminin analyysit ja otamme heiltä vain yleisen näkökulman (Schmittiltä näkemyksen tragediasta esi-oikeudellisen päätöksen tilana ja Benjaminilta näkemyksen tragediasta sanan konfliktina), voimme kysyä eri näkökulmasta lähinnä strukturalistisen antropologian avustamana, miten antiikin tragedia suhteutui kielen konfliktista syntyvän poliittisen järjestyksen perustan ongelmaan? Aristoteleen sanoin tragedia jäljittelee elämän päämäärän muodostavaa toimintaa, joka perustaa onnellisen ja onnettoman kohtalon..$^{30} \mathrm{Se}$ jäljittelee siis politiikkaa aristoteelisessa mielessä. Mutta kuten Benjamin totesi, tragedian ytimessä on tuota toimintaa ohjaavan sanan, homonymian konflikti. Jos Antigoneella ja Kreonilla olisi sama merkitys laille, eli jos konflikti olisi ratkaistavissa sanojen kesken, ei tragediaa olisi. Antiikin kaupunkivaltion, poliksen tasa-arvoisuus perustui sanalle, ja Euripideen mukaan ei ole muuta tasa-arvoista kun sanat. Mutta kuten Aristoteles totesi homonymian ongelmasta: "Sanat ovat rajallisia määrältään, kun taas asiat ovat rajattomia ja yhtä nimeä täytyy välttämättä vastata usei- 
ta asioita." ${ }^{11}$ Tragedia kukoistaakin epiikan jälkeen jakautuneen sanan ongelmasta tietoiseksi tulleessa Ateenan demokratiassa, mutta filosofia tuhoaa sen monopolisoimalla vakavan sanan mietiskelyn. Samoin komedia merkitsee jo vieraantuneempaa, kaupungistuneempaa sanojen leikkiä tehden poliksen järjestyksen historiallisilla ja horisontaalisilla rajoilla seisovista hybriksen myyttisistä hahmoista pilkattavia maalaistolloja. Aristoteleelle hyvä nopeaälyisyys onkin kasvatettua hybristä ja keskitie yhtäältä sanoja ja asioita erottamattoman, väkivallan uhkaa mukanaan kuljettavan maalaistollon hybriksen, toisaalta juurensa unohtaneiden ja kaikelle nauravien liikaa kaupunkilaistuneiden sofistien hybriksen välillä. ${ }^{32}$

Tragedia taas käsittelee rajoja ja perustavan (väki)vallan hybriksen ongelmaa ja ammentaa aineksensa legendojen perustajasankareista. Tragedia on sidottu myyttiin, mutta tragediarunoilijan muokkaamaan, juoneksi kehittyvään myyttiin. Tragedia on myytin esitys, ja vaikka emme pysty enää kokemaan kuoron rytmiä tai myytin elävyyttä, eivätkä "naiset saa keskenmenoja ja lapset pyörry"33 tragedioita luettaessa, on turha luulla, että kreikkalainenkaan yleisö sulautui dionyysisessä ekstaasissa kuoron tanssiin; se erosi siitä aivan kuten orchestra, ei-paikka, loi tilan esityksen esityksellisyydelle erottaen kuoron ja yleisön tilallisesti. Naamioimaton kuoro ei ole kansa vaan ennemminkin kansan esitys itsestään, kansan joka käy vuoropuhelua varsinaiset poliittiset päätökset tekevän, naamiolla yksilöidyn sankarin toiminnan kanssa. ${ }^{34}$ Mutta tragedia ei enää juhli yksinäistä sankaria vaan on sankarin toimintaan sisältyvän myyttisen väkivallan kritiikkiä. ${ }^{35}$ Sanan ja muistin herra, eeppinen runoilija, ei enää laula yksinkertaisesti sankarin urotöiden loistoa. Tragedia on enemmän "valtion taidetta", Ateenan poliksen itsejuhlintaa. Kuitenkin se eroaa toisesta Ateenalle erityisestä lajityypistä, julkisesta hautajaispuheesta yhteisille sankarivainajille. Jälkimmäisessä aristokraattinen katoamaton loisto muunnetaan kaupungin kuolemattomaksi muistoksi, ja näin ylistävä sana muuttaa vain sisältöään aristokraateista demokraatteihin. Aristokraattisemmassa tragediassa sen sijaan säilyy jännite aristokraattisten ja kaupungin uusien arvojen välillä. ${ }^{36}$ Tragediarunoilija esittää sankarin ongelmallisena juuri runoilijan hallitseman sanan suhteen. Kohdatessaan monimielisen sanan ja oikeuden konfliktin itse sanat kääntyvät toiminnan sankaria vastaan. Tragedian jakaantunut sana ei kuitenkaan ole sofistien dissoi logoi, jossa sana hajoaa teesin ja antiteesin mekaniikaksi, vaan monimielinen, arvoituksellinen ja kahdentunut sana.

Esi-oikeudelliseen lain monimielisyyteen liittyvässä tragediassa kiista näyttäytyy vielä keskeisenä, mutta samalla myytin monimielisyys on jo laskussa ja kiistan hiljainen sovitus tapahtuu näkyvää konfliktia perustavammassa näkymättömässä järjestyksessä. Näkyvän kiistan ja näkymättömän harmonian ajattelijan Herakleitoksen toteamus ihmisen olemisen tavan jakaantumisesta ja demonisuudesta (ethos anthropo daimon) ohjaa tragiikkaa. ${ }^{37}$ Mutta vaikka traagisen ironian ydin on mahdottomuudessa erottaa ihmi- sen luontoa ja kohtalon voimia, edellyttää tragedia jännitteen näiden välillä. Iiliaksen sankarit toimivat jumalten heittopusseina, itse agonististen jumalten määräämän satunnaisen hyvän (eudaimon) ja huonon (dysdaimon) onnen vallassa olematta traagisia. Traagisimpanakin pidetty Akhilleus muistuttaa vain kiukuttelevaa pikkulasta. ${ }^{38}$ Tragedian jumalat eivät juokse sankarien rinnalla sankarijumalina, vaan jumalten näkymätön viisaus on erotettu näkyvästä maailmasta ilmaantumaan vain oraakkelimaisesti arvoituksen kautta. Keskeiseksi tulee näkyvän ja näkymättömän risteys, jolla myös tragedian esitystekniikka pelaa esittäen kauheimmat ja jumalalliset toiminnat yleisöltä ja näyttämöltä piilossa, esittämättöminä. Tragediassa ihminen ei vapaudu jumalista kuten tragedian humanistisessa tulkinnassa, vaan tragedia varoittaa näkyvän maailman hybriksestä, ihmisen luulosta omistaa itse sanan totuus. Tragedia, kuten Platonin filosofia, on sofistien humanistisen hybriksen - ihminen on kaiken mitta - kritiikkiä.

Myyttisen hahmon perustavasta väkivallasta on siis tullut tragedialle ongelma. Kun Homeroksen Odysseus seisoo kosijoiden veren tahraamana ruumiiden keskellä, saavat nuo "veren viljat" riemuun Eurykleia-orjan, joka tunnistaa herransa loistavan ruumiin verrattoman työn tekemisestä. ${ }^{39}$ Näkyvän vallan hybriksestä juopunut tragedian Kreon taas, seistessään Antigonen lopussa vuodatetun veren keskellä, on kauhea näky, ja orjien on vietävä pois päivänvalosta se, "jota ei enää ole". ${ }^{40}$ Kreon ei myöskään ole vielä stoalainen, joka 
sieluunsa linnoittautuneena seisoo tapetun perheensä ja tuhotun omaisuutensa keskellä täysin itseriittoisen järkkymättömänä maailman sattumia vastaan. ${ }^{41}$ Tragedian sankarilla ei ole stoalaista oikean omatunnon (orthe $s u$ neidesis) suojaa, vaan itseriittoisuus on hybristä, jonka tragedian jumala Dionysos hajottaa. Tragedian sankarin omatunto (suneidesis) on ainoastaan hiljaista kärsimystä kahden sanan konfliktin edessä: "Älkää vain luulko, että ylpeydestäni tai itserakkaudestani olen vaiti. Ei, vaan omatunto sydäntäni jäytää." ${ }^{42}$

Onkin muistettava, että esioikeudellisessa tilassa sukujen itseriittoisen hybriksen väkivallan kontrolli ilmaistiin "kollektiivisen", jumalallisen saastumisen tai hedelmättömyyden rangaistuksen kautta. ${ }^{43}$ Ateenan tragedian lempiaiheita olikin kilpailevan kaupungin, myyttien ja legendojen Theban, oikeamielisen Ateenan symbolisen vastakuvan, myyttinen hallitsijasuku Labdakidit, jotka ontuvat kaupunkinsa tavoin oikeasta järjestyksestä. ${ }^{44}$ Legendan mukaan Labdakos on rampa, jonka jalat eivät täsmää ja joka on näin kykenemätön oikeaan mittaan. Hän on siis tyrannin lailla kykenemätön oikean mitan mukaiseen hallitsemiseen. Tämän poika Laios on liian pieni ottamaan isänsä paikan tämän kuollessa. Suvun järjestys katkeaa, ja vieraan hallitsijan astuessa isän ja pojan väliin Laios karkotetaan. Laios saa turvapaikan Pelopsin luota, mutta kömpelö ja vasenkätinen Laios rikkoo sekä oikean vieraanvaraisuuden että oikean rakastajan ja rakastetun symmetrisen vaihdon raiskaamalla väkivaltaisesti hybriksisessä himossaan
Pelopsin pojan Khrysippoksen, joka raiskauksen seurauksena tappaa itsensä. Poikansa menettänyt Pelops kiroaa Laioksen suvun hedelmättömään tuhoutumiseen. Labdakoksen väärän ja ontuvan hallitsijasuvun on kadottava. Kun Laios haluaa hankkia itselleen hyväsyntyisen pojan, perintönsä jatkajan, osoittautuu tämä äpärääkin pahemmaksi. Kirouksen takia Laios harrastaa vain poikkeavaa hedelmätöntä yhteyttä vaimoonsa, mutta yhtenä iltana humalassa hän erehtyy aukoista ja siittää itselleen laillisen, kirotun pojan, Oidipuksen, jonka jalat lävistetään ja jätetään Kithairon rinteille kuolemaan.

Labdakidien taru saa kuuluisamman versionsa Sofokleen trilogiassa, ja Sofokleen versiossa labdakidien legendan kautta me kohtaamme poliittisen perustan ja hybriksen ongelman suhteessa sanan konfliktiin. Sofokles tuo näyttämölle kolme vallanpitäjää: Kreonin ja Oidipuksen traagiset hahmot sekä tylsimmän, mutta oikeaa poliittista järkeä omaavan Theseuksen. Viimeisessä tragediassa Oidipus Kolonoksessa Sofokles näyttää kuitenkin kieltävän uhrauksellisen rakenteen päätymättä kuitenkaan myöskään melankoliseen marttyyriyteen. Mutta luokaamme tätä ennen pinnallinen ja yleinen katsaus siihen, mikä on Kreonin ja Oidipuksen kaupunkivaltion ylistämää poliittista järkeä tottelematon hybris.

\section{KREONIN HYBRIS}

Antigone on saanut olla modernille maailmalle sankaritar, vaikka Kreon on hahmo, jossa tapahtuu varsinainen traaginen käänne. Kuoleman pakkomielteen vaivaama ("kuolleita vain auttaa voin") eksistentialisti Antigone seuraa loppuun asti vain omaa sanaansa, ja ainoaksi tragediaksi jää se että jumalat, joita hän rukoilee, eivät pelasta häntä. Antigonen jumalat eivät olekaan Olympoksen jumalia vaan arkaaisempia, esivanhempien tapojen asettamia, Mykenen hautakammioiden jumalia. ${ }^{45}$ Antigonen yön pimeydessä suorittama yksityisten ja maanalaisten jumalten lakien seuraaminen asettuu suoraan Kreonin julkisia päivänvalon julistuksia vastaan. Naisen neuvottelematon halu veren äänen seuraamiseen joutuu konfliktiin miesten julkisen poliksen kanssa, joka on pyrkinyt ylittämään yksityisen verikoston kierteen. Näyttää siltä kuin Antigonen yksityinen tuska kävisi itse tragedian kimppuun, sillä eikö tragedia ollut yhteinen esitys ja julkinen juhla? Kleisthatoksen sanottiin omistaneen kuorotanssit Dionysokselle ja siirtäneen ne pois yksityisistä hautajaisista. ${ }^{46}$ Dionysos, vieras hedelmällisyyden jumala, sisäsiittoisuuden eli endogamian vihollinen, naamioiden jumala, joka hajottaa oman ja identiteetin, yhdistää ulkoapäin poliksen ja luo sisällissodan tilalle harmonian. ${ }^{47}$ Voimakkaan suvun itseriittoisuus esiintyi usein myyteissä juuri insestinä ja naisjäsentensä kontrollina. Dionysos taas pakottaa naiset ulos kotoa mielettömään himon villiin juoksuun Kithairon rinteille ja rankaisee kultistaan kieltäytyviä hulluudella, jossa nämä repivät omat esikoisensa kappaleiksi. ${ }^{48}$

Samoin poliksen keskeinen uudistus oli yhteinen sankarivainajakultti ja mahdollista eripuraisuutta luovien yksityisten hautajaisten kritiik- 
ki. ${ }^{49}$ Kreonin kielto haudata poliksen vihollinen, veljesvihan ja sisällisodan aloittanut Polyneikos ei tässä yhteydessä näytä kohtuuttomalta. Solonin kerrotaan kieltäneen järjestetyt vaikeroimissessiot hautajaisissa, ja varsinkin naisten raivokasta, mieletöntä, väkivaltaista, hiuksia ja vaatteita repivää itkua pidettiin surun ja vaikeroinnin kautta kuolleeseen yhdistyvänä ja vaarallisena, elävät ja kuolleet sekoittavana mimesiksenä. ${ }^{50}$ Tätä on Antigonen nekrofiilinen rakkaus veljeensä ja halu asettaa yhtyminen sukuunsa Hadeessa vaihdettavaa aviomiestä ja lapsia tärkeämmäksi. Vaihdosta kieltäytyvä Antigone kääntää ympäri kreikkalaisen naisen sukujen vaihdon ja suhteiden symbolin - matkan omasta suvustaan avioliiton kautta toiseen sukuun. ${ }^{51}$ Antigonen aviovuode on insestinen kuolinvuode, ja Antigone näkee vain menneen, ei tulevaa. Siksi tämä kaupunkivaltiolle ulkopuolinen, apolis, on insestisen sukunsa viimeinen, toisin kuin eloon jäänyt Ismene, joka tulevaisuuden nimissä on valmis sovittamaan itsensä poliksen tulevaisuuteen.

Mutta myös maan poikien, maansyntyisten myytin ohjaama Ateena tarvitsee poliittisen kiistan ja kielen vaihdon paikalleen sitovaa yhteistä traditiota ja muistia. Jos paikka viittaa aina omaan ja omaisuuteen, oli yksi ratkaisu yhteisen poliittisen tilan luomiseen juuri perustaa se poissaolevan, kuolleen sankarin paikalle - ensimmäiset poliittiset neuvostot syntyivätkin juuri haudan kultille. ${ }^{52}$ Kuollut sankari ilmensi sekä tarvetta paikallistettuun perustaan että sankarin persoonallisen vallan häviämiseen ja sen siirtämiseen yhteisesti häntä seuraaville miehille. Sankarin, rajojen määrittäjän ja yhteisen maailman avaajan muisto loi yhteisen muistin. Jos kreikkalaisen kulttuurin erityisyys oli eriksen ja filian, kiistan ja ystävyyden yhteys, niin hauta absoluuttisen synkronian sijana vakautti sotureiden diakronisen agonistiikan, samoin kuin kaupungin kulttirituaalit siirsivät agonistisen kisailun poliksen vakaiksi instituutioiksi. Polis, kuten jokainen poliittinen järjestelmä, tasapainoili näin jähmettävän rituaalin ja avoimen leikin välillä; liian suuri rituaali kuolettaa toiminnan suolapatsaiksi ja liian suuri leikki hajottaa sen määrittämättömäksi anarkiaksi. ${ }^{53}$

Jos siis Antigonen hybris on pitää haamut elossa ja sekoittaa kuolleet ja elävät, on Kreonin hybris kuolleen sankarin tyhjälle paikalle astuminen ja politiikan ulkopuolen kieltäminen. Poliksen puolustamisen nimissä Kreon haluaa torjua naisen yksityisen hybriksen vaaran, mutta sortuu itse julkiseen hybrikseen luullessaan voivansa toteuttaa kuoron sanoja: "Lakia voithan käyttää miten tahdot vain kuolleihin nähden kuin myös suhteen eläväin. ${ }^{54}$ Myös Kreon sekoittaa kuolleiden ja elävien järjestyksen asettamalla käskyn haudata elävä ja olla hautaamatta kuollut. Vielä aluksi Antigonen uhkana on kivityskuolema, julkinen yhteinen teloitus, joka on mahdotonta ilman kansan suostumusta, mutta elävältä hautaamisen kohtuuton rangaistus ei enää perustu kansan tukeen. Kreon ei enää tunne poliittiselle järjelle keskeistä kohtuutta ja sovittamista, vaan hänestä on tullut tyranni. Kreonin päätös ei perustu enää myöskään lakiin vaan puhtaaseen tyrannin käskyyn, joka sekoittaa ihmisen voiman oikeudenmukaisuuteen. Kreonista on tullut mieletön ja kohtuuton, vallasta on tullut hybristä, väkivaltaa. Kreon on sofisti, joka irrottaa lait pelkiksi suvereenin määräyksiksi, antiikin Hobbes, joka haluaa lopettaa väkivallan uhkaa kantavan yksityisten omatuntojen riidan hallitsijan ehdottomalla käskyllä. Kreon uskoo taistelevansa naisen himossa ruumillistuvaa yksityistä hybristä vastaan: "On mielivalta kaikkein pahin: kaupungit se tuhoaa [...]. Järjestystä tulee puolustaa ja koskaan ei saa myöten antaa naiselle." ${ }^{55}$ Mutta väittelyssään poikansa Hamonin kanssa hän on tehnyt poliksesta omansa. "Vain yhden miehen maa ei ole valtio. Hallitsijanko oma eikö valtio? Erämaan päämies, yksin, oisit mainio." 56 Kohtuuttomassa kostossaan vihollisen ruumista kohtaan, aivan kuin tämä olisi vielä elävä, Kreon saastuttaa uudestaan kaupungin. Hän ei anna veljesvihan unohtua Hadeessa vaan jättää Polyneikeksen ruumiiseen sisältyvän väkivallan uhan kiertelemään koirien ja lintujen, luonnon kuljettamana anarkistisena väkivaltana. Itse mielipuolisuuteen syyllistynyt Kreon kääntyy itsepäisyydestään vasta kuoron käännyttyä viisaan tietäjän Teiresiaan puolella. Mutta kun Kreon vihdoin ymmärtää, että "paras miehen kunnioittaa lakeja perittyjä kautta elämän", 57 on kohtalokas virhe jo tehty. Suvun lain kieltäneen Kreonin kohtalona on menettää oma poikansa Haimon, verensä (aimo) ja sukunsa jatkumo, ja tulla näin itse elävältä haudatuksi. "Ei elävältä hän sen jälkeen näytä, hengittävä ruumis hän vain on." ${ }^{58}$ Julkisen valosta sokaistunut 
avaa silmänsä nyt näkymättömälle haluten paeta päivänvaloa, vaikka näkyvän hybriksessä hän ei suostunut kuuntelemaan sokean näkijän Teiresiaan näkymätöntä järkeä. Lopussa kuoro ylistääkin tilanteeseen soveltuvaa ja ennakoivaa poliittista viisautta ja järkeä (fronesis), jota Kreonin olisi pitänyt kuunnella. ${ }^{59}$

Teiresiaalla, viisaan prototyypillä, on varhaisen runonlaulajan kyky, omalla sokeudellaan ostamansa toinen näkö. Arkaainen runonlaulaja, logoksen herra, kokee menneen läsnä omassa ajassaan muistinsa kautta. Muisti on se mikä näkee menneen ja tulevan, näkyvän takana piilevän näkymättömän, kuten sokea Teiresias. Tarun mukaan hän sokaistui samoillessaan kaukana poliksen rajojen ulkopuolella ja nähdessään sen mitä kuolevaisten ei tule nähdä, alastoman Pallas Athenen. Athenen soturinaisen hahmossa yhtyykin poliksen järjestykselle perustava erottelu hopliittisoturin ja naisen, julkisen ja yksityisen välillä, ja myös Teiresias, hermafrodiitti, on itse tämän polikselle perustavan sukupuolijaon, riidan yhteensovittava hahmo. Toinen tarina kertookin hänen sokeutuneen Heran rangaistuksesta, koska tiesi arvoituksen vastauksen, jota jumalatkaan eivät tienneet, maailman järjestyksen perustassa olevan kahden erilaisen olion yhteyden arvoituksen, miehen ja naisen nautinnon arvoituksen. ${ }^{60}$

\section{OIDIPUKSEN HYBRIS}

Myös Oidipus kuninkaassa (tai paremminkin tyrannissa) Teiresias, viisaudessaan jumalten kaltainen, pyrkii varoittamaan näkyvästä vallasta sokeutunutta ja jumalten kaltaiseksi voimassaan noussutta sankaria Oidipusta. Varhaisissa legendoissa Oidipus ei ole traaginen hahmo vaan toiminnan mies, joka voittaa sivilisoivana sankarina Sfinksin, naisen ja eläimen sekoituksen, puhtaalla miehisellä voimallaan ja hallitsee tämän jälkeen Thebaa. Homeros kertoo Oidipuksen kuolleen taistelussa ja jumalten tehneen tiettäväksi hänen insestisen onnettomuutensa.$^{61}$ Sofokleella jumalat eivät enää ilmaise Oidipuksen kohtaloa ilman tämän omaa arvoituksen ratkaisuun pyrkivää toimintaansa, ja Oidipuksen kohtalo kietoutuu sanan tragediaan. Sfinksin valta on nyt sanan arvoituksessa eikä toiminnan miehen voitto Sfinksistä ole enää ongelmaton. Oidipus ei ole viisas vaan pikemminkin helposti suuttuva ja nopeasti toimiva käytännön mies. Oidipus, "kärsimätön", kantaa äkkipikaista väkivallan hybristä mukanaan. Hän hermostuu helposti Teiresiaalle, uhkaa tappaa Kreonin, ja kuvatessaan kuinka tappoi Laioksen sanoo tehneensä sen vihan puuskassa. ${ }^{62}$ Teiresiaalle hän vastaa uhmaakkaan ironisesti, että juuri hän, Oidipus tietämätön, voitti Sfinksin, ei viisas Teiresias. Voitto nostaa Oidipuksen jumalten vertaiseksi sankariksi, tai ainakin hän on nyt "ihminen varmin kuolevaisten tavoin". ${ }^{63}$ Mutta Oidipuksen, joka tietää (oida), varmuus on tietäjän viisautta halveksuvaa kuolevaisen varmuutta. Samalla kun tämä sanaa minä hokeva arvoitusten ratkaisija on varma itsestään ja tietonsa voimasta, kuljettaa hänen sanansa ironista kaksoiskohtaloa, jota hän ei tiedä. Oidipuksen puhe pettää jatkuvasti itsensä, ja kuitenkin ainoa totuus on hänen omissa sanoissaan, joita hän ei ymmärrä. Oraakkelin mukaan jumalat tietävät ja puhuvat totuuden mutta antavat sen ilmaantua sanoissa, jotka näennäisesti ilmaisevat jotakin muuta. ${ }^{64}$

Oidipuksen tappaessa Laioksen tämä oli menossa hakemaan apua Delfoin oraakkelilta Sfinksin ongelmaan, mutta Oidipus itse voittaa nuoria vallananastajia testaavan ja syövän Sfinksin ja pelastettuaan kaupungin syöjättäreltä nousee itse sen hallitsijaksi. ${ }^{65}$ Vakuuttuneena nimensä tuomasta tiedon kyvystä (oida) Oidipus luulee voittaneensa tiedollaan oraakkeleiden viisauden, mutta paksujalka (oidipus) ei tunne jalkansa (pous) kohtaloa. Oidipuksen toiminta on sidottu käsiin, jotka korostuvat tekojen lähteenä ja kohtalon toimeenpanijoina. Omilla käsillään hän surmaa isänsä ja myös sokeuttaa itsensä. "Vaan vammakäsi muu ei käynyt, itse iskin." ${ }^{66}$ Sen sijaan kohtalo, jota Oidipus yrittää välttää, on sidottu tämän rampoihin jalkoihin, joita hän yrittää peittää. Syntymässä lävistetyt jalat kuljettavat ontuvan nilkun väärään risteykseen, murhapaikkaan, jossa äkkipikaiset kädet suorittavat teon, ja lopulta Oidipus vaeltaa karkotettuna jalkojensa viemänä. Jalat ja kädet, kohtalo ja toiminta, ovat kaksi ihmisen puolta.

Sfinksin arvoitus koskee juuri jalkoja. Mikä on se, joka on nelijalkainen, kaksijalkainen ja kolmijalkainen? Arvoitus erottaa ihmisen kokemuksen sfäärin nuoruuteen, aikuisuuteen ja vanhuuteen. ${ }^{67}$ Oidipus, jonka jalkojen kantama kohtalo on vieras, apolis, ihmisen kokemukselle, on ratkaisu arvoitukseen, koska hänen kohtalonaan on 
juuri tuoda ihmisen kokemuksen sfäärit yhteen naidessaan äitinsä ja ollessaan lapsiensa veli. Oidipus, tiedon sankari, ratkaisee antiikin kartesiolaisena kokemuksen viisauden arvoituksen yhdessä ajallisessa oman egonsa välttämättömässä pisteessä erottaen näin tiedon, kokemuksen ja etiikan. Hän sekoittaa sen minkä olisi pitänyt olla erillistä. Ajattomuudessa elävillä jumalilla ja eläimillä insesti ei ole ongelma, ja tyranni voi tehdä mitä vain. Kaupungin porttia vartioivan, sen väkivaltaisen elementin sisältävän Sfinksin arvoituksen ratkaisu ei itse asiassa ole ihminen, joka ei ole koskaan samaan aikaan lapsi, aikuinen ja vanhus, vaan Oidipus Tyranni. Eräiden versioiden mukaan Oidipus ei vastannutkaan arvoitukseen vaan hämillään osoitti pelkästään itseään kädellään (toiminnallaan) ratkaisten näin tietämättä jalkojensa (kohtalon) arvoituksen.

Mutta tuo ratkaisu on vain illusorinen ja jättää itse Oidipuksen, kaupungin uuden, perustavan väkivallan monopolin hallitsijan, arvoituksen hämärään. Pakkomielteessä ratkaista oman syntymänsä arvoitus Oidipus ei kuuntele varoittavia vihjeitä vaan haluaa sumeilematta ratkaista perustan ongelman ja perustaa oman vallananastajan valtansa. Mutta kun Oidipus löytää oikeutetun kuninkuutensa Theban hallitsijasuvun esikoispoikalapsena, tapahtuu tunnistamisen hetki ja perustan väkivallan ongelma avautuu. Oikeudenjakaja paljastuu rikolliseksi, kaupungin suojelija ja pelastaja sen saastuttajaksi, lääke myrkyksi, Oidipus farmakokseksi. ${ }^{68}$ Suvereenin väkivallan kahdet kasvot ilmaantuvat, ja näkyvän valtansa hybrikseen luottanut Oidipus sokeuttaa itsensä.

\section{THESEUKSEN VIISAUS}

Vanhuudessa, elämän ja kuoleman rajalla, jossa toiminta ja kohtalo tulevat yhteen ja pyyteitä ei enää ole, Sofokles kirjoittaa tragedian Oidipus Kolonoksessa. Siinä ei esiinny enää Teirasiasta, ja nyt Oidipuksen hallitsijan valtikka on vaihtunut vanhusta tukevaan ja sanansaattajan symbolina toimivaan keppiin. Oidipus ei ole enää ontuva kaksijalkainen vaan tetrapus, sokea vanhus, luonnollisesti kokemuksen läpi kulkenut, jonka jumalankaltaisuus ei ole enää näkyvässä voiman hybriksessä vaan osallisuudessa näkymättömästä järjestyksestä näkijän tapaan. Hän saapuu Ateenan rajoille muukalaisena ja vieraana, kuten hän kerran saapui Thebaan. Nyt hän ei kuitenkaan ole vallananastaja vaan turvan anoja. Vieraanvarainen Ateena ottaa hänet vastaan aivan kuten tragediassa se otti vastaan vieraan, Thebasta saapuvan jumalan, Dionysoksen. Oidipus on yhä apolis, pyhä ja kirottu, jonka insestisessä kohtalossa jumalallinen ja eläimellinen yhtyvät. Hän on kerran tai paremminkin jo kahdesti kuollut ja näin uhrauksen tuolla puolen. ${ }^{69}$ Mutta nyt Oidipuksen hybris on poissa; ennemminkin hänen pyhä ja kirottu asemansa on tulosta jumalten jo tässä maailmassa antamasta rangaistuksesta ja yhteydestä ajattomaan. Enää kyse ei ole toiminnan hybriksestä, vaan Oidipus on viaton tekoihinsa. Nimi yksinomaan on vastuussa hänen kohtalostaan, ja kuten Aristoteleskin myöhemmin toteaa, nimisana ilmaisee aina ajatonta. Oidipus kärsii enemmän kuin toi- mii. Ateenalaiset pelkäävät aluksi näitä kärsimyksiä, kunnes ymmärtävät, että Oidipus on oikeamielinen mies, jonka voima lepää nyt sanassa, ja sen tähden kaikessa, mitä hän sanoo, tulee olemaan näky.

Kreon Theban hallitsijana on jälleen toiminnan tyranni, jolle Oidipus vastaa: "On minulla tekojasi vastaan vain sanani asettaa." ${ }^{70}$ Jos Oidipus tyrannina oli metsästäjä, joka joutuikin metsästetyksi, ihmisen väkivallan kantaja, joka joutui tuon väkivallan uhriksi, niin nyt Kreonista sanotaan: "Saalistaja on itse satimessa, metsästäjä astunut omaan ansaansa." 71 Oidipus ei enää etsi Thebaan paluuta, ei siunaa poikiensa veljesvihaa, vaan kiroaa sotaa lietsovat poikansa ennustuksellaan - "toistenne vereen hukutte". ${ }^{72}$ Polyneikes, joka rikkoo isänsä kunnioituksen, ei ole Thebasta vapautuneen Oidipuksen poika vaan Theban lohikäärmeen sikiö. Ateenalle Theba on esitys hybriksen, tyrannian ja veljesvihan rienaamasta, itseensä suljetusta mutta sisäisesti jakautuneesta järjestyksestä. ${ }^{73}$ Theseus, Ateenan myyttinen sankari, taas asettuu näkymätöntä järjestystä kunnioittavaksi hallitsijaksi. Häntä ei kutsuta tyranniksi vaan kuninkaaksi (basileus), oikeudenmukaiseksi mieheksi ja kaupungilleen vastuussa olevaksi hallitsijaksi. Theseus ei päätä Oidipuksen kohtalosta ilman kansan tukea, ja kuoro päättää hyväksyä Oidipuksen, samalla tragedian julistaessa, ettei Ateena päätä mitään ilman lain kunnioitusta.

Oidipus ei ole enää Theban kansalainen, hän on vaeltaja ilman maata, josta karkotus on tehnyt apoliksen, mutta hän saa ja ei saa Ateenan kansalaisuuden, joka alkaa ja 
loppuu hänen mysteerisessä kuolemassaan. Hänen suojeleva pyhä ja kirottu ruumiinsa, jossa jumalten ja ihmisten järjestys on yhtynyt, saa paikattoman paikan Ateenan rajaseuduilta, jossa vieraat tulevat yhteen ja jossa jumalat, ihmiset ja eläimet kohtaavat. Häntä ei saateta Ateenaan eikä hänestä myöskään tule Kolonoksen Oidipusta vaan Oidipus Kolonoksessa, kuolevaisia suurempi sankari, jonka ruumis on Ateenan suojana. Mutta sankarin suojeleva hauta on nyt ei-missään, atooppinen Sfinksin paikka. ${ }^{74}$ Vain sokea Oidipus, toisen näkökyvyn omaava, voi johdattaa itsensä tuolle paikalle, jota kuolevaiset eivät saa nähdä. Oidipus kulkee kohti rajoja, paikkaan, jossa Theseus ja Peirithos, lapiittien kuningas, solmivat ikuisen ystävyyden valan, lähelle kivistä hautaa, jossa luonnon ja ihmisen järjestys yhtyvät. ${ }^{75}$ Siellä Oidipus häviää kenenkään tietämättä, veivätkö hänet taivaan vai maan jumalat. Oidipus, joka koki jo elämässään tavalliselle kuolevaiselle vasta kuolemassa tapahtuvan toiminnan ja kohtalon yhdistymisen, kulki kuolemaansa ilman kärsimystä. "Ei vienyt häntä sota, ei meri vaan aivan kuin hän olisi astunut läpi näkymättömän portin näkymättömään maailmaan." ${ }^{" 76}$

Theseus "ainoana saa nähdä sen mikä on muiden silmiltä ja korvilta kielletty", ${ }^{77}$ perustan mysteerin, jossa olevien järjestykset yhtyvät ja jota hän ei saa sanoin kavaltaa vaan vasta elämänsä päätöksessä paljastaa seuraajalleen. Jos hän näin tekee, on Ateena turvassa Theban lohikäärmeen sikiöiltä, veljesvihan riivaaman kaupungin kohtalolta. Oidipuksen kadottua Ateenan sanansaattajat näke- vät yksin kuninkaansa, "joka varjellakseen silmiään oli kohottanut molemmat kätensä kasvojensa suojaksi, aivan kuin hänelle olisi ilmestynyt jokin hirmuinen näky, jota hän ei kestänyt katsoa". ${ }^{78}$ Tämän jälkeen alkaa Oidipuksen tyttärien ahdinko, "en kestä enää", "kaikki on menetetty", halu jatkaa uhrauksen logiikkaa, "Oi vertajanoava Ares, tässä on Uhrisi". ${ }^{79}$ Antigone ei tiedä mihin tuskansa laittaisi ja haluaa yhtyä isänsä kohtaloon, löytää haudan, jossa voisi riistää kärsimyksen itseltään. Mutta Oidipus on rikkonut uhrauksen rakenteen, ja "mitään hautaa ei ole", 80 ei kuoleman sovitusta elämän tuskaan. Ei ole paikkaa, jonne tuska perusteettomuudessaan voitaisiin perustaa. Kuoro ilmoittaa ettei tuskalta välty kukaan elävä, ja Theseus kysyy, miksi tuo yletön murhe: "Ei teillä ole mitään syytä halveksua elämäänne [...]. Kuivatkaa kyyneleenne, arvon neidot!"81 Oidipuksen viimeinen pyyntö Theseukselle oli, ettei yhdenkään kuolevaisen tule vuodattaa suruaan hänen haudallaan. Vain silloin olisi Ateena pelastettu ja maa ilman kärsimystä mahdollinen. Pitäisikö meidän nähdä tässä vain varhainen arcana imperii, kuninkaan salaisuus ja perustan poissaolo mystisenä perustana kyyniselle poliittiselle vallalle, vaiko naurettava ateenalainen itsetyytyväisyys, tai kenties sittenkin radikaali yritys rikkoa kuoleman ja perustan suhde, kielen ja kuoleman suhde, yritys ylittää kuolema negatiivisena perustana? Tragedia päättyy joka tapauksessa kuoron sanoihin: "Nyt vaiti valitus! Ei kyyneltäkään. On asiat näin päätetty." 82

Kyynelten ja vaikeroinnin sanaton ääni ei siis lunasta sanojen konfliktia, ja näin itse traaginen sovitus kielletään, samalla kun tragedian uhrauksen logiikka murretaan. Oidipus ei ole enää traaginen sankari, ihmisen demonisen jakautuman konfliktin perusteettomuuden - väkivallan - väkivaltainen ratkaisuyritys, poliittisen järjestyksen perustava ja siitä samalla ulossuljettu poikkeus. Mutta kyse ei ole myöskään marttyyriydestä - kieltämällä suru ja vaikerointi perustaa kohtaan hävitetään myös tyhjennetyn transsendentin luoma kaiho, huimaus ja päättämättömyyden melankolia. Oidipus yksinkertaisesti häviää kokonaan jättäen vain salaisuutensa näkyvän maailman suojaksi, ja kenties Theseuksen hallitsijan poliittinen viisaus on vain tuon tyhjän salaisuuden tiedossa, ja kaikkein kauhein näky, joka saa kuninkaan suojaamaan kasvonsa, on juuri se, ettei mitään nähtävää ollut.

\section{Markku Koivusalo}

\section{$v i \mathrm{itte}$ e t}

1. Kuten Hannah Arendt kirjoitti teoksessaan Origins of Totalitarism: "Porvarillinen luokka, joka oli selvinnyt sosiaalisesta paineesta alituisen poliittisten instituutioiden taloudellisen kiristämisen kautta, uskoi aina, että julkiset ja näkyvät vallan elimet olivat heidän oman salaisen ja yksityisen intressinsä ja vaikutusvaltansa ohjaamia. Tässä mielessä porvarillinen poliittinen filosofia oli aina totalitaarista. Se oletti aina politiikan, talouden ja yhteiskunnan identtisyyden, jossa poliittiset instituutiot palvelivat ainoastaan yksityisten intressien fasadina. Porvarillinen kaksinaismoraali, 
sen julkisen ja yksityisen erottaminen, oli myönnytys kansallisvaltiolle, joka oli epätoivoisesti yrittänyt pitää nämä alueet erillään." (Arendt 1973, 336.) Tämän porvarillisen maailmankuvan yhteisen hyväksynnän takia Brechtin Kerjäläisooppera, joka esitti gangsterit kunnioitettavina liikemiehinä ja kunnioitettavat liikemiehet gangstereina, ei voinut toimia Hitleriä edeltävässä Saksassa. "Roskajoukko taputti koska se otti viittauksen kirjallisesti, porvaristo taputti koska se oli antanut oman tekopyhyytensä huijata itseään niin kauan, että se oli väsynyt jännitteeseen ja löysi syvää viisautta sen banaliteetin ilmaisemisesta missä se eli, eliitti taputti koska tekopyhyyden paljastaminen oli niin suurta ja ihmeellistä hupia. Teoksen vaikutus oli juuri vastakkainen sille mihin Brecht oli pyrkinyt. Porvaristoa ei voinut enää shokeerata. Se toivotti tervetulleeksi salatun filosofiansa paljatumisen, jonka suosio paljasti sen olleen oikeassa alusta asti." (Arendt 1973, 335.)

2. Schmitt 1985, 1987.

3. Näkemys liittyy Schmittin poliittisen romantismin kritiikkiin. Ks. Schmitt 1986.

4. Schmitt lainaa Lohensteinia Benjaminin kautta: "Yksikään elämä ei todista enemmän näytelmästä ja teatterista kuin se mikä valitsee hovin elämässä" (Benjamin 1985, 93).

5. Foucault 1997.

6. Tämä oli Schmittille uuden ajan valtion keskeinen uudistus. (Erityisesti suhteessa Hobbesiin ks. myös Koselleck 1988.) Schmittille myös aikakauden sodat jus europeum publicumin aikana olivat eräänlaisia säännöllistettyjä leikkisotia tai paremminkin näytelmiä. Schmitille merelle suuntautuva kaappareita ja merirosvoja hyväkseen käyttävä Englanti jättäytyi suljetusta valtiosta avoimemmaksi. Ennen Elisabetin aikaa Englanti oli lähinnä lammasfarmareiden maa, joista Elisabet teki meren lapsia ja loi näin nousevan kapitalismin ja meren liiton. $\mathrm{Na}$ - poleonin, maakeisarin, tappio merkitsi Englannin merivallan ylivaltaa maailmassa. "Kuin kala, se kykeni uimaan toiseen paikkaan maapallolla." Merivallasta tuli taas teollisen vallankumouksen myötä insinöörivalta ja "oltuaan siihen asti kala, Leviathan alkoi muuttua koneeksi." (Schmitt 1997.)

7. Kyse ei ole katseesta näyttämön taakse, modernista näyttelijän näytelmästä, jossa näyttämö paljastetaan, naamiot riisutaan ja näyttelijä esittää itsensä alastomassa ihmisyydessään, ja jossa väärä julkinen alue paljastetaan itse näyttämöllä, eli julkisen alueen omassa teatterissa (Schmitt 1987). Schmitt piruilee samalla niille, jotka redusoivat taiteen materiaalisiin ja sosiaalisiin ehtoihin. Schmittille ongelma oli se että "saksalaisilla ei ole muuta jäljellä kuin valinta joko dialektisen materialismin tai esteettisen kauneuden ilmenemisen välillä." (Lain. Dotti 1999.)

8. Schmitt 1987.

9. Joulukuussa 1930 Benjamin lähetti kirjansa ja kirjeen Schmittille: "Tulette hyvin nopeasti huomaamaan kuinka paljon kirjani on velkaa teidän esityksellenne 1600-luvun suvereniteetin opista. Kenties voin myös lisäksi kertoa, että olen myös saanut myöhäisemmistä teoksistanne, erityisesti teoksesta Die Diktatur, ja tavastanne tutkia valtion filosofiaa vakuutuksen omalle tavalleni tutkia taiteen filosofiaa." (Lain. Weber 1995.) Schmitt väittikin olleensa yhteydessä Benjaminiin 30-luvun alussa päivittäin ja kirjoitta-neensa Hobbes-kirjansa vastauksena tämän Trauerspiel-tekstille. (Ks. Bredekamp 1999.)

10. Erityisesti "Historian teesien" kehittely säännöksi tulleesta poikkeustilasta voidaan lukea suhteessa Schmittin teorioihin. Jacob Taubesin mukaan ne kirjoitettiin suorana vastauksena Schmittille.

11. "Luterilaisuus [...] tekemällä sekulaaris-poliittisesta alueesta testauspaikan elämälle, joka oli ainoastaan epäsuorasti us- konnollista ja tarkoitettu lähinnä kansallishyveiden osoittamiseen [...], asetti ihmiseen ankaran tottelevaisuuden ja velvollisuuden tunteen, mutta sen suurissa miehissä se tuotti melankoliaa" (Benjamin 1985, 138). Benjaminin barokkitulkinnan suhteesta sekularisaatioon ja "lumouksen" haihtumiseen ks. myös Rochlitz 1992.

12. Benjaminin huomautus siitä, että Hamletin elämä melankolian kohteena viittaa kristilliseen pelastukseen, ei tarkoita Hamletin luottamusta tuonpuoleiseen vaan lunastuksen idean säilyttämistä.

13. Benjamin 1985, 136-137.

14. Benjam in 1985, 137

15. Benjamin 1985, 66.

16. Barokkisekularisaatio ei Benjaminille tarkoita modernia sekularisaatiota. Kaikesta maallistumisesta huolimatta uskonnolliset instituutiot eivät menettäneet merkitystään ainoastaan mahdollisuuden uskonnolliseen lunastukseen. Itse asiassa tuolloin kristinuskon auktoriteetti oli kyseenalaistamaton. (Benjamin 1985, 79.)

17. Benjamin 1985, 92.

18. "Murhenäytelmässä hovi esittää ajatonta, historiallisen prosessin luonnollista décoria." Benjamin 1985, 93.

19. Benjamin 1985, 65.

20. Ks. Schmitt 1997.

21. Ks. Benjamin 1985. Benjaminille kuten Schmitille itsestään selvä teokraattisuus on ajatunut kriisiin. Etenkin Hamletissa kuninkuus on enää vain nimi, haamu. Ernst Kantorowitz käsitteli ennen kaikkea Shakespearen Richard II:a näytelmänä kuninkaan kahden ruumiin ongelmasta ja Elisabet näki näytelmässä viitteen itseensä. (Ks. Kantorowitz 1957.)

22. Benjamin 1985, 71.

23. Ks. Schmitt 1996.

24. Huom. myös Aristoteleen näyttämöä tragediassa vähättelevä huomautus: "Lisäksi tragedia saavuttaa päämääränsä myös ilman liikettä, kuten epiikka, sillä sen ominaisuudet käyvät esiin myös luettaessa" ( $R u$ nousoppi 1462a10-2). Näyttämöstä ks. myös Lacoue-Labarthe \& Nancy 1998. 
25. Ks. Benjamin 1985; 1996a; 1996b; 1996c, 203. Vielä vuoden 1916 esseessään murhenäytelmästä Benjamin kirjoittaa, että siinä missä traaginen koskee sanan konfliktia, murhenäytelmä ylevöittää luonnon musiikiksi (Benjamin 1996c). Kuitenkin barokki-kirjassaan Benjamin ei näytä enää antavan musiikille tällaista asemaa, vaan ooppera merkitsee nyt murhenäytelmän degeneraatiota. Kenties kysymys on Nietzschen itsekritiikkiin tutustumisesta. Nietzsche, joka vielä Tragedian alkuperässä antoi musiikille ja wagnerilaiselle oopperalle lunastavan roolin, asettui myöhemmin rankasti tätä nuoruuden romantismiaan vastaan (ks. Nietzsche 1967).

26. Siinä missä Weimarin tasavalta näyttäytyi Schmittille päätöstä vaativana kriisin tilana, etsi Benjamin tilanteesta, jossa historiallinen kokemus näyttäytyi raunioina ja itse kokemuksen mahdottomuutena, kuitenkin uuden toivon mahdollisuuden siemeniä. NatsiSaksa sittemmin päätti kriisin tekemällä "poikkeustilasta säännön" ja keräsi kokemuksen rauniot uudeksi myytiksi estetisoimalla politiikan. Opportunistisia romantikkoja kritisoinut Schmitt päätti nyt sopeutua uuteen järjestykseen, ja toivonsa menettänyt melankolinen Benjamin kuoli Hamletin tavoin lähes sattuman johdosta. Sen jälkeen tosin Benjaminin allegorinen jäämistö on lunastettu useaan otteeseen.

27. Tämä teema on tietenkin kehittynyt lähinnä viime vuosisadan saksalaisen filosofian piirissä ja ilmaantuu nykyään varsinkin Hölderlinistä uudelleen innostumisen kautta. Tässä en kuitenkaan puutu tähän traditioon, vaikka varsinkin Benjaminin pohdinnat liittyvät siihen selkeästi. Benjaminille Hölderlinin myöhäiskausi ja tämän Sofokles-käännökset edustavat kuitenkin allegorisessa tekniikassaan juuri runoilijan barokkijaksoa.

28. Schmittistä modernin traagisuuden traagisena ajattelijana ks. Galli 1996.
29. Aikamme barokkiluonnetta on haluttu tulkita negatiivisesti silloin, kun barokki on nähty yksinkertaistettuna absolutismin juhlintana ja kansan alistamisena spektaakkelille. Tosin tällöin on uusinnettu kaikki modernin renessanssinihailun aiheuttamat ennakkoluulot barokkia kohtaan. Toisaalta taas on juhlittu nykyajan barokkimaista labyrinttimäisyyttä ja allegorista fragmentaarisuutta (kuten Buci-Glucksmann 1994). Omaperäisimmän ja kiinnostavimman barokkirinnastuksen aikaamme on kuitenkin tehnyt Gilles Deleuze taitteen käsitteen kautta (Deleuze 1993).

30. "Sillä tragedia ei ole ihmisten jäljittelyä, vaan se jäljittelee toimintaa ja elämää ja onnellisuutta ja onnetonta kohtaloa. Onnellisuus ja onneton kohtalo perustuvat toimintaan, ja päämäärä elämässä on tietynlainen toiminta, ei tietynlainen oleminen." Runousoppi, 1450a 15.

31. Sofistien kumoamiset, 1, $165 \mathrm{a} 11$.

32. Aristoteles: Nikomakhoksen etiikka 1128a, Retoriikka 1389b11. Maalaistollon mielikuvasta antiikin Kreikassa ks. Borgeaud 1995. "Vähemmän myytistä riippuvaisena komedia keksi maalaistollon" (mt., 293). Aristofanes esittää komediassaan "Sammakot" tämän sanojen vakavuuden menetyksen jo erona Aiskhyloksen ja Euripideksen välillä. Vanhempi traagikko on lähempänä oraalista kulttuuria ja sanojen ja asioiden vastaavuutta, kun taas Euripides yhdistetään sofistiseen liikkeeseen ja sanojen leikkiin.

33. Aiskhyloksen visuaaliefektien lumouksen sanottiin aiheuttavan keskenmenoja ja lasten pyörtymistä (ks. Segal 1995).

34. "Tragedia oli yksi muodoista, joiden kautta uusi demokraattinen kaupunki asetti identiteettinsä [...], se otti kaukaisesta myytistä 'kuningas kääntyy tyranniksi' hahmonsa, asetti tämän näyttämölle arvioitavaksi, esitti tämän väärät valinnat, jotka johtivat katastrofiin" (Vernant 1990f, 257).
35. "He [sankarit] ovat tavallaan julkisen tutkiskelun alla. Lauluissaan kuoro on vuorostaan vähemmän kiinnostunut ylistämään sankarin esimerkillisiä hyveitä, kuten lyyrisessä traditiossa Simonediksesta Pindariin, kuin tuomaan esiin ahdistuksen ja epävarmuuden sankaria. Siten traagisen vaihtelun uudessa kehikossa sankari on lakannut olemasta malli ja tästä on tullut sekä itselleen että toisille ongelma." (Vernant 1990b, 25).

36. "Tragedia edellyttää luonnostaan vastakohdan kahden sanan välillä, agon logon, kun taas hautajaispuhe on diskurssia, joka ei odota vastausta." Loraux 1986, 216. Voidaan myös huomata, että aristokraattisia arvoja puolustava Platon ei koskaan pilkkaa niin pahasti tragedian jäljittelyä kuin hautajaispuheen. "Puhujan sanojen kaiku soi korvissani niin kauan, että vasta neljäntenä tai viidentenä päivänä vaivoin muistan kuka ja missä olen" (Meneksenos 235c).

37. Fragmentti 114. Ks. Kahn 1979.

38. Ks. myös Vähämäki 1998.

39. Odysseus, XXII 408-409.

40. Antigone 1456.

41. Ks. Seneca 1964.

42. Aiskhylos: Kahlehdittu Prometheus, 436-438. Omatunnon (suneidesis) teemasta tragediassa ja länsimaisen tiedon suhteesta mykkään perustaan, jota se ei voi ratkaista, ks. Agamben 1991. Agamben ei kuitenkaan korosta traagisen ja filosofisen omatunnon/tietoisuuden eroa vaan näkee platonisen "ajattelun kivun kanssa ilman sanaa" olevan täysin yhteensopiva tämän Aiskhyloksen traagisen lausuman kanssa. Kuitenkin jo Sokrateella se sai äänen, ja stoalaisessa ajatuksessa oikeasta omatunnosta/tietoisuudesta (orthe suneidesis) se tuli edustamaan ihmiskunnan ylintä varmuutta. Agambenin mukaan logiikka, asettamalla tiukat rajat sille mikä voidaan tietää ja sanoa, ottaa tämän hiljaisen äänen ja tekee siitä kaiken tiedon negatiivisen perustan. Näin tämä traaginen hiljainen 
ääni on mystinen, puhumaton, perusta koko kulttuurillemme ja ainoastaan tämän mysteerin eliminoiminen voi avata alueen tulevalle ajattelulle.

43. Epidemian oikeudenmukaisuudesta ks. mm. Vlastos 1946.

44. Ks. Vernant 1990c. Oikean ja vasemman normatiivisuudesta Kreikassa ks. Vidal-Naquet 1986. Thebasta myyttien, Dionysoksen ja Oidipuksen kaupunkina ks. myös Kerenyi 1959.

45. Olympoksen jumalien uudesta kosmologiasta ks. Vernant 1989. Konflikti yksityisen ja julkisen, naisen ja miehen välillä ja näiden "säilyttävä ylittäminen" tekee tietenkin Antigonesta Hegelille keskeisen tragedian esityksenä siveellisyyden laista. Ks. mm. Hegel 1994, \$160. Antigonesta taas singulaarisen singulaarisuutena, joka kuitenkin vastustaa universalisointia, jonka Hegel väittää tekevänsä luennassaan, ks. Lindberg 1983.

46. "Mutta Kleisthenes omisti kuorotanssit Dionysokselle." $\mathrm{He}$ rodotus, 5., 67.

47. Euripides: Bakkanaatit 208209.

48. Ks. Detienne 1979, 1989.

49. Kuolleiden ylistäminen oli vähän aikaa Solonin lain jälkeen kielletty muuten paitsi julkisissa hautajaisissa toimeen julkisesti nimitetyn puhujan toimesta. Ks. Seaford 1994.

50. "Naiset yhdistettiin uskollisuuteen tilayhteisölle ilman yhdenkään julkisen roolin lievennystä ja miehiä suurempaan suremisen intensiteettiin, joka voi tuottaa hallitsemattomia vaateita kostoon." Seaford 1994, 84.

51. Ks. Vernant 1990d.

52. François Polignac näyttää tutkimuksessaan kreikkalaisen kaupungin alkuperästä, kuinka ensimmäisen poliksen elin, aristokraattinen neuvosto, määriteltiin usein haudan kultin paikan perusteella - Iiliassa Troian johtajat kokoontuvat Iloksen (tarunhohtoisen Troian "isän") haudan juurelle. (Polignac 1995, 143-144).

53. Pelin ja rituaalin suhteesta ks. Agamben 1978.

54. Antigone, 238-239.
55. Antigone, 751-758.

56. Antigone, 824-825.

57. Antigone, 1237-1238.

58. Antigone, 1286

59. "Yläpuolella viisaus (to fronein) kaiken on muun, mikä onneen vie [...]. Ylimielinen mies - tuo korskeasuu - velat maksava on kovat: vanhana hän on viisautta oppiva viimein." (Antigone 1466-1470.) Vastakohta "käytännöllisen" järjen (fronesis) ja viisauden (sofia) välillä on vasta aristoteelista perua (Aubenque 1963, 164).

60. Pallas Athenen hahmosta ks. Vernant 1990a. Amatsonien soturinaisista myyttisenä poliksen vastakuvana ks. Tyrrell 1994. Jumalan näkemisen sokaisevasta vaikutuksesta ks. Vernant 1991. Ennen Teiresiasta kukaan ei ollut nähnyt alastonta Pallas Athenea, miehistä soturinaista ilman varustuksia ja ilman miehistä varustusta. Näkikö Teiresias sukupuolettomuuden? Gorgon katseen Athenen silmissä? Viriilin neitsyen fallisen ruumiin? Vai salatun feminiinisen ruumiin miehisyyden alla? Tai kenties hän ei nähnyt juuri mitään? Kreikkalaisen nuoren neitseen ruumiin, joka kuvataan vain negaation kautta, ei-olevana? Hieno analyysi siitä, mitä Teiresias näki/ei-nähnyt nähdessään neitsytsoturin alastomana: ks. Loraux 1995.

61. "Sotiessa kun Oidipus sortui." Iilias 23., 679, "Ja niin isän surmasi, äidin nai oma poika, mut ilmi sen taivahaiset pian saattoi." Odysseia 11., 271-280.

62. Oidipus Kuningas, 891.

63. Oidipus Kuningas.

64. Ks. Vernant 1990f. Aristoteleen mukaan "arvoituksen periaate on, että tosiseikoista puhutaan mahdottomilla yhdistelmillä" Runousoppi 1458a 26-27. Arvoituksen merkityksestä kreikkalaisessa viisauden kilvoittelussa ks. myös Colli 1997.

65. Tarinasta on olemassa jopa versio, jossa Sfinksi oli Laioksen äpärätytär, jonka tehtävänä oli testata kuninkaan pojat erottaakseen oikeutetut äpäristä (Vernant 1990c).

66. Oidipus Kuningas, 1469-1471.
67. Kaikissa trilogian osissa Sofokles näyttää viittavan tuon arvoituksen olevan ratkaistavissa vain kokemuksen tuoman matkan kautta. Hieman eri näkökulmasta Michel Foucault tosin näkee Oidipuksessa juuri kokemuksen, "seikkalijan", vaaroille altistuneen tiedon sankarin, joka tietää liikaa, ja yhdistää Sofokleen tragedian vaiheeseen, jossa koettelemukseen liittyvä arkaaisen Kreikan oikeuskäytäntö on väistymässä tiedusteluun perustuvan tieltä. Koettelun mestarin tuo alas sekä profeetallinen tieto (Teiresias) että todistus (paimenet) jotka symboli puolikkaat yhteen tuovana vallan käytäntönä sitoo yhteen. Ks. Foucault 1994.

68. Oidipuksesta farmakoksena ks. Vernant 1990e. Analyysistä farmakoksesta supplementtina, lääkkeenä ja myrkkynä, ja kirjoituksesta länsimaisen filosofian farmakoksena ks. Derrida 1991. Erityisesti tästä kvasitranssendentaalina ja mahdottomana mahdollisuusehtona ks. Hintsa 1998. Poliittisessa roolissaan farmakos voidaan sijoittaa perustavan väkivallan ongelmaan. René Girard, jolle Oidipus esittäytyy todisteena tämän mimeettisen väkivallan teoriasta, näkeekin Oidipuksen syntipukkina ja farmakokseen liittyvän "hyvän" ja "pahan" väkivallan kantajana. Hienoista pohdiskeluistaan huolimatta Girard kuitenkin yksinkertaistaa kuviota ja samoin Teiresiaksen ja Oidipuksen kaksintaistelun lukeminen mimeettisenä väkivaltana ei oikein näytä toimivan. (Ks. Girard 1977.) Kuten Louis Gernet on todennut, on homo sacer latinalaisen kulttuurin vastine farmakokselle (Gernet 1968), ja Giorgio Agambenin luenta homo sacer -hahmosta näyttäisi tässä huomattavasti hedelmällisemmältä. Koko Oidipustriologia voitaisiin lukea myös suhteessa Agambenin käsittelemään homo sacer-hahmoon. Homo sacer on elämän hahmo, joka on otettu suvereeniin pannaan ja joka säilyttää muiston alkuperäisestä ulossulke- 
misesta, jonka kautta poliittinen ulottuvuus muodostettiin. Kyse on elämän hahmosta, jota ei voida uhrata ja joka voidaan tappaa tekemättä murhaa. Kyse ei ole siis luonnollisesta elämästä ( $z o e$ ) eikä elämäntavasta (bios) vaan elämästä ihmisen ja pedon, luonnon ja kulttuurin, konstitutiivisessa ja erottamattomassa alkuperässä. (Agamben 1995.)

69. Tässä jälleen yhteys Homo Saceriin ja erityisesti sen yhteys devotus-hahmoon. Jälkimmäinen omistaa elämänsä kuolemalle pelastaakseen kaupungin suuresta vaarasta. Mutta jos hän ei kuole, tulee hänestä yhteiskunnalle ongelmallinen elävä ruumis, joka "jo kuolleena", "jumalille omistettuna" ja kuitenkin elävänä ei enää kuu-

Agamben, Giorgio (1991): Language and Death: The Place of the Negativity. University of Minnesota Press. Minneapolis.

- (1978): "In Playland. Reflections on History and Play". Teoksessa Infancy and History. Verso.

- (1998): Homo Sacer. Verso.

Aiskhylos: Kahlehdittu Prometheus. Gaudeamus 1975.

—: "The Past and Present". Teoksessa Vernant \& Vidal-Naquet: Myth and Tragedy in Ancient Greece. Zone Books, New York 1990.

Arendt, Hannah (1973): The Origins of totalitarianism. New York 1973.

Aristoteles: Teokset. Gaudeamus 1991-1998.

Aubenque, Pierre (1963): La prudence chez Aristotle. PUF.

Benjamin Walter (1985): The Origin of German Tragic Drama. Verso.

- (1996): Selected Writings. Volume 1, 1913-1926. Harvard University Press.

- (1996a): "Fate and Character". Teoksessa Benjamin: Selected Writings.

- (1996b): "The Role of Language". Teoksessa Benjamin: Selected Writings.

- (1996c): "Trauerspiel and Tra- lu elävien maailmaan. Häntä ei voida palauttaa elävien maailmaan, koska juuri hänen kuolemalle omistautumisensa kautta yhteisö pelastui. Samoin homo sacerin ruumis, kyvyssään tulla tapetuksi mutta ei uhratuksi, on elävä vakuus tämän alistuksesta kuoleman vallalle, vakuus, joka on ehdoton, jopa ilman omistautumisenkin lunastusta. (Ks. Agamben 1995.)

70. Ks. Oidipus Kolonoksessa.

71. Oidipus Kolonoksessa, 1173.

72. Slatkin 1986, 1555-1556.

73. Vastakohtana sisäisesti jaettuun mutta ulkoisesti suljettuun Theban kaupunkiin Ateena esittää itsensä avoimena ulos ja sisäisesti jakamattomana (ks. Vidal-Naquet 1990; Zeitlin 1985).

\section{K I R J A L L ISUUS}

gedy". Teoksessa Walter Benjamin: Selected Writings.

Blake Tyrrell (1994): Amazons, A Study in Athenian Mythmaking. The John Hopkins University Press.

Bourgeaud Philippe (1995): The Rustic. Teoksessa Vernant (ed.:) The Greeks. Chicago Press.

Bredekamp, Horst (1999): "From Walter Benjamin to Carl Schmitt via Thomas Hobbes". Critical Inquiry 25.

Buci-Glucksman Christine (1994): Baroque Reason.

Deleuze Gilles (1993): The Fold. Minnesota University Press.

Derrida, Jacques (1981): Dissemination. The University of Chigaco Press.

Detienne Marcel (1979): Dionysos Slain. Johns Hopkins University Press.

- (1989): Dionysos at Large. Harvard University Press.

- (1996): The Masters of Truth in Archaic Greece. Zone Books.

Dotti, J. E. (1999): "From Carl to Karl”. Teoksessa Moffe (toim.): The Challange of Carl Schmitt. Verso 1999.

Foucault, Michel (1997): Il Faut Défendre la Société. Gallimard.

- (1994): "La vérite et les formes juridiques". Teoksessa Dits
74. Aristoteles toteaa Fysiikassa, että asiat, jotka ovat, ovat jossakin, ja ei-oleva ei ole missään, "sillä missä vuohihirvi tai sfinksi on?" (Aristoteles: Fysiik$k a$ 208a, 30). Sfinksi on ruumiiton ei-oleva, atooppinen ja siksi vailla paikkaa.

75. Rajaseutujen ja tilojen keskeisyydestä teoksessa Oidipus Kolonoksessa ks. Vidal-Naquet 1990.

76. Ks. Oidipus Kolonoksessa.

77. Ks. Oidipus Kolonoksessa.

78. Oidipus Kolonoksessa, 18711875.

79. Ks. Oidipus Kolonoksessa.

80. Oidipus Kolonoksessa, 1954.

81. Oidipus Kolonoksessa, 19211922.

82. Oidipus Kolonoksessa, 2000.

and écrits II. Gallimard.

Galli, Carlo (1996): Genealogia della politica. Carl Schmitte la crisi del pensiero politico moderno. Il Mulino.

Gernet, Louis (1968): Anthropologie de la Gréece antique. Maspero.

Girard, René (1977): Violence and the sacred. The John Hopkins University Press.

Hegel, G.W.F. (1994): Oikeusfilosofia. Prometheus.

Herodotus: Historia-teos. Wsoy 1907.

Hintsa, Merja (1988): Mahdottoman rajoilla. Tutkijaliitto.

Homeros: Iilias. WSOY 1919. Suom. Otto Manninen.

—: Odysseia. WSOY 1924. Suom. Otto Manninen.

Kantorowitz, Ernst (1957): The King's two bodies. Princeton University Press.

Kerényi. C (1959): The heroes of the Greeks. Thames and Hudson.

Koselleck, Reinhart (1988): Critique and Crisis. Berg.

Lacoue-Labarthe, Philippe \& Nancy, Jean-Luc (1998): Scene: An exchange of letters.

Lindberg, Susanna (1993): Absoluuttinen muisti ja muita muistoja. Teoreettisen filosofian 
pro gradu. Helsingin yliopisto. Loraux, Nicole (1986): The Invention of Athens. The Funeral Oration in the Classical City. Harvard University Press.

- (1995): The Experiences of Teiresias. The Feminine and the Greek man. Princeton University Press.

Nietzsche, Friedrich: The Birth of Tragedy. Vintage Books, 1967.

Platon: Teokset I-VII. Otava, 19781990.

Polignac, François de (1995): Cults, Territory, and the Origins of the Greek City State. The University of Chigaco Press.

Proust, Françoise (1994): L'Histoire á Contretemps. La temps historique chez Walter Benjamin. Cerf.

Rochlitz, Rainer (1992): Le désenchantement de l'art. La philosophie de Walter Benjamin. Gallimard.

Seaford Richard (1994): Reciprocity and Ritual. Homer and Tragedy in the Developing CityState. Clarendon Press 1994.

Seneca: Tutkielmia ja kirjeitä. WSOY, 1964.

Segal, Charles (1995) teoksessa Vernant (toim.): The Greeks. Chigaco Press.

Schmitt, Carl (1985): Hamlet oder Hekuba. Der einbruch der Zeit in das Spiel. Klett-cotta.

- (1986): Political Romanticism. MIT Press.

- (1987): "The Source of the Tragic". Telos 72 .
- (1996): Roman catholicism and political form. Greenwood Press.

- (1997): Land and Sea. Plutarch Press.

Slatkin, Laura (1986): "Oedipus at Colonus: Exile and Integration”. Teoksessa Greek Tragedy and Political Theory, edited by P. Euben. University of California Press.

Sofokles: Antigone. Suom. E. Vaara. WSOY 1966.

—: Kuningas Oidipus. Suom. O. Manninen. WSOY 1966.

—: Oidipus Kolonoksessa. Suom. E. Kirkkopelto. Like 1994.

-: The three Theban Plays. Englanninnos Robert Fagles. Penquin Classics 1984.

Vlastos Greogory (1946): "Solonian Justice". Classical philology XLI.

Vernant, Jean-Pierre (1989): The Origins of Greek Thought. Cornell University Press.

- (1990): Myth and Society in Ancient Greece. Zone Books, New York.

- (1990a): "City-State Warfare". Teoksessa Vernant: Myth and Society in Ancient Greece.

- (1990b): "The Historical Moment of Tragedy in Greece: Some of the Social and Psychological Conditions." Teoksessa Vernant \& Vidal-Naquet: Myth and Tragedy in Ancient Greece.

- (1990c): "The Lame Tyrant. From Oidipus to Periander". Teoksessa Vernant \& VidalNaquet: Myth and Tragedy in Ancient Greece.
— (1990d) "Marriage". Teoksessa Vernant: Myth and Society in Ancient Greece.

- (1990e): "Tensions and Ambiquities in Greek Tragedy". Teoksessa Vernant \& VidalNaquet: Myth and Tragedy in Ancient Greece.

— (1990f): "Ambiquity and Reversal: On the enigmatic structure of Oidipus Rex". Teoksessa Vernant \& Vidal-Naquet: $M y t h$ and Tragedy in Ancient Greece.

Vernant, Jean-Pierre \& Vidal-Naquet, Pierre (1990): Myth and Tragedy in Ancient Greece. Zone Books, New York.

- (1991): Mortals and Immortals. Princeton University Press. New Jersey.

Vidal-Naquet, Pierre (1986): The Black Hunter. The Johns Hopkins University Press.

- (1990): "Oedipus between the Two Cities. An Essay on Oedipus at Colonus". Teoksessa Vernant \& Vidal-Naquet: Myth and Tragedy in Ancient Greece.

Vähämäki, Jussi (1997): "Ennen politiikkaa”. Tiede E edistys 1/97.

Weber, Samuel (1992): "Taking exception to decision: Walter Benjamin and Carl Schmitt". Diacritics 22.

Zeitlin, Froma I. (1986): "Thebes: Theater of Self and Society in Athenian Drama”. Teoksessa P. Euben (toim.): Greek Tragedy and Political Theory. University of California Press. 